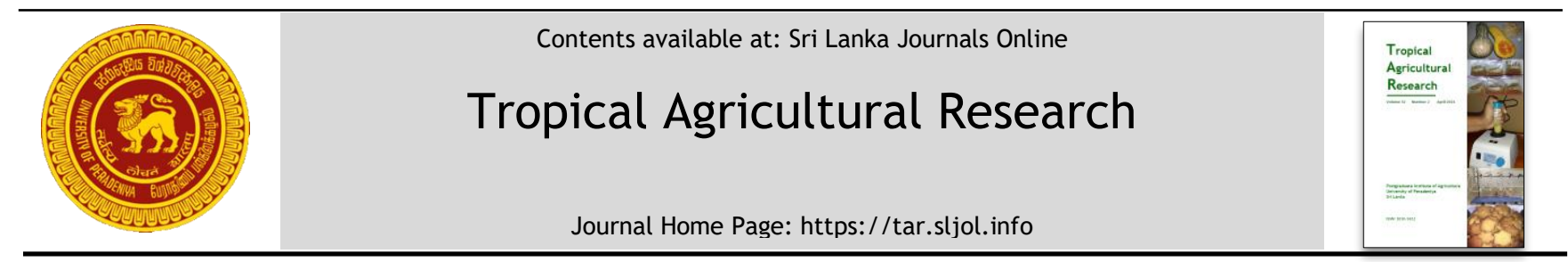

\title{
Spatial and Temporal Changes of Homegarden Land Use as a Tree Resource Outside Forests in Upper Mahaweli Catchment of Sri Lanka: Biophysical and Socioeconomic Determinants of Major Changes
}

\author{
H.M.B.S. Herath ${ }^{1 *}$, D.K.N.G. Pushpakumara ${ }^{2}$ M. Hewson ${ }^{3}$ and P. Wickramagamage ${ }^{4}$ \\ ${ }^{1}$ Department of Geography, University of Sri Jayewardenepura, Gangodawila, Nugegoda, Sri Lanka. \\ ${ }^{2}$ Department of Crop Science, Faculty of Agriculture, University of Peradeniya, Peradeniya, Sri Lanka. \\ ${ }^{3}$ Department of Geography and Environment, University of Central Queensland, Australia. \\ ${ }^{4}$ Department of Geography, Faculty of Arts, University of Peradeniya, Peradeniya, Sri Lanka
}

\section{ARTICLE INFO}

\section{Article history:}

Received: 23 September 2020

Revised version received: 1 December 2020

Accepted: 25 January 2021

Available online: 1 April 2021

\section{Keywords:}

Land use

Homegardens

Spatiotemporal changes

Upper Mahaweli catchment

Tree Resources Outside Forests

\section{Citation:}

Herath, H.M.B.S., Pushpakumara, D.K.N.G., Hewson, M. and Wickramagamage, P. (2021). Spatial and Temporal Changes of Homegarden Land Use as a Tree Resource Outside Forests in Upper Mahaweli Catchment of Sri Lanka: Biophysical and Socioeconomic Determinants of Major Changes. Tropical Agricultural Research, 32(2): 229-242.

DOI: http://doi.org/10.4038/tar.v32i2.8470

Hearath, H.M.B.S,

https://orcid.org/0000-0002-6697-0742

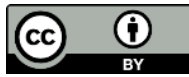

\section{ABSTRACT}

Tree rich homegardens as Tree Resources Outside Forests (TROF) consider as one of the major land use systems in the Upper Mahaweli Catchment (UMC). Homegardens play a significant role in reducing negative impacts and protecting the catchment in areas where lack of forest cover. The main objective of this study was to analyze spatial and temporal changes of homegarden land use of UMC and to analyze determents for the major change. A multi-temporal spatial assessment was carried out using geospatial tools and techniques utilizing Landsat images acquired in 1992 and 2017. Eight prominent land uses in the catchment were classified to prepare land use maps and for change detection. Determinants for the major land use change was assessed by employing a multiple regression model using environment, spatial, demographic, and socioeconomic variables. Results revealed that forest area remains the same for the past 25 years in UMC while area under homegardens has been increased by $60 \%$. The major land-use change was the other agricultural crops-based land use into homegardens. Elevation, proximity to main road, proximity to town centers, population density, education level, and poverty were significant determinants for the change. The negative and significant $(\mathrm{p}<0.01)$ relationship between land use change from other agricultural crops into homegardens and elevation implies that there is a low tendency for change into homegardens in higher elevations. Therefore, effective measures should be taken to control unsustainable land uses at higher elevations and incentives should be introduced to enhance the quality of homegardens to maintain the sustainability of the UMC.

*Corresponding author: badra.usjp@gmail.com 


\section{INTRODUCTION}

Homegardens as Tree Resources Outside Forests (TROFs) are becoming eminent land uses in Sri Lanka due to their ecological, environment and socio-economic significance. FAO (1998) defines TROF as trees and tree systems that occupy lands that are not defined as forest and other woodland. They provide a wide range of ecosystem services including catchment protection functions as a forest already do (FAO, 2013). Upper Mahaweli Catchment (UMC) is in the central highlands, considered as the heart of the country due to its environmental, hydrological and socio-economic significance to the country. Number of negative consequences due to land use changes in UMC have been shown by various researchers (Hevawasam, 2010; Wijethunga Bandara, 2013; Hewavisenthi, 1997; Wikramagamage, 1990; Gunawardhana et al., 2018).

Homegarden is one of the major land uses in Upper Mahaweli Catchment. Tree rich homegardens are one of the best substitutes to compensate the loss of forest cover in the catchment since tree rich homegardens are analogue to a forest patch which provide number of ecosystem services (Ariyadasa, 2002; Pushpakumara et al., 2012). Therefore, homegardens located in the UMC play a vital role in maintaining the sustainability of watershed functions while providing other various biophysical and socio-economic benefits to the country. Considering these factors, policies, and legislations such as forest policy, agriculture policy and soil conservation act have identified importance of homegardens as a multifunctional land use system (Pushpakumara et al., 2012). However, land use changes of the UMC including homegardens have been experienced over the last three decades due to various reasons. Thus, quality of homegardens has been also changed due to conversion, fragmentation and changing the species composition. These changes resulting loss of ecosystem services derived from homegardens in the UMC as well as reduced environmental and socio-economic benefits of the watershed.

Spatial distribution and changes of homegardens over the past decades within the catchment are not known. Proximate and underlying drivers or determinants that effect on land use changes of homegardens with respect to spatial and temporal perspective are not sufficiently analyzed scientifically. Due to these information gap relevant policy makers face challenges in setting appropriate policy strategies to enhance the quality of homegardens to maintain the sustainability of environmental and socio- economic benefits derived from the UMC in Sri Lanka. Therefore, the main objective of this study was to analyze spatial and temporal changes of homegarden land use as a TROF in UMC of Sri Lanka and to assess biophysical and socioeconomic determinants of major changes. Specific objectives were to identify and quantify spatial distribution of homegarden land use in 1992, and 2017, to detect temporal changes of homegarden land use from 1992 to 2017 and to assess biophysical and socioeconomic determinants for major changes.

\section{METHODOLOGY}

\section{Study area}

The study area is the Upper Mahaweli Catchment (UMC) of Sri Lanka (Figure 1). The location of the UMC, is between longitude $80^{\circ} 25^{\prime}$ to $81^{\circ} 01^{\prime} \mathrm{E}$ and latitude $6^{\circ} 45^{\prime}$ to $7^{\circ} 30^{\prime} \mathrm{N}$ and encompasses areas in Central, Uva and Sabaragamuwa provinces (Ranjith Premalal De Silva, 1997). Elevation of study area ranges from $2,717 \mathrm{~m}$ at Pidurutalagala (Gibbon, 1990) which is the highest summit in the country, to $150 \mathrm{~m}$ at Rantembe. Majority of the area of UMC is belonged to the Wet Zone of the country except a small patch of belongs to the Intermediate Zone. Precipitation is seasonal and heavy with variations from $1,000 \mathrm{~mm} /$ year up to 5,500 $\mathrm{mm} /$ year. Total surface area is $3,110.81 \mathrm{~km}^{2}$ with the sub-catchments of Kotmale, Victoria, Randenigala, Rantembe and Uma Oya. It has a rugged topography, with a mean slope gradient varying from $5^{\circ}$ to $30^{\circ}$. Five main soil types have been identified within the catchment where Red Yellow Podzolic soil is the dominant soil group, covering approximately $60 \%$ of the area (Hevawasam, 2010).

\section{Spatiotemporal assessment}

Spatiotemporal assessment of land uses involved two major stages. First stage was devoted for the preparation of land use maps and the second stage devoted for post classification change detection. First stage comprised of image classification and preparation of land use maps for the years of 1992 and 2017 of the UMC area based on the following procedures.

\section{Acquisition of spatial data}

Freely downloadable images (Landsat series) were acquired from United State Geological Survey (USGS). In addition, Google images and topographic maps of 1:50,000 scale prepared by the Survey 


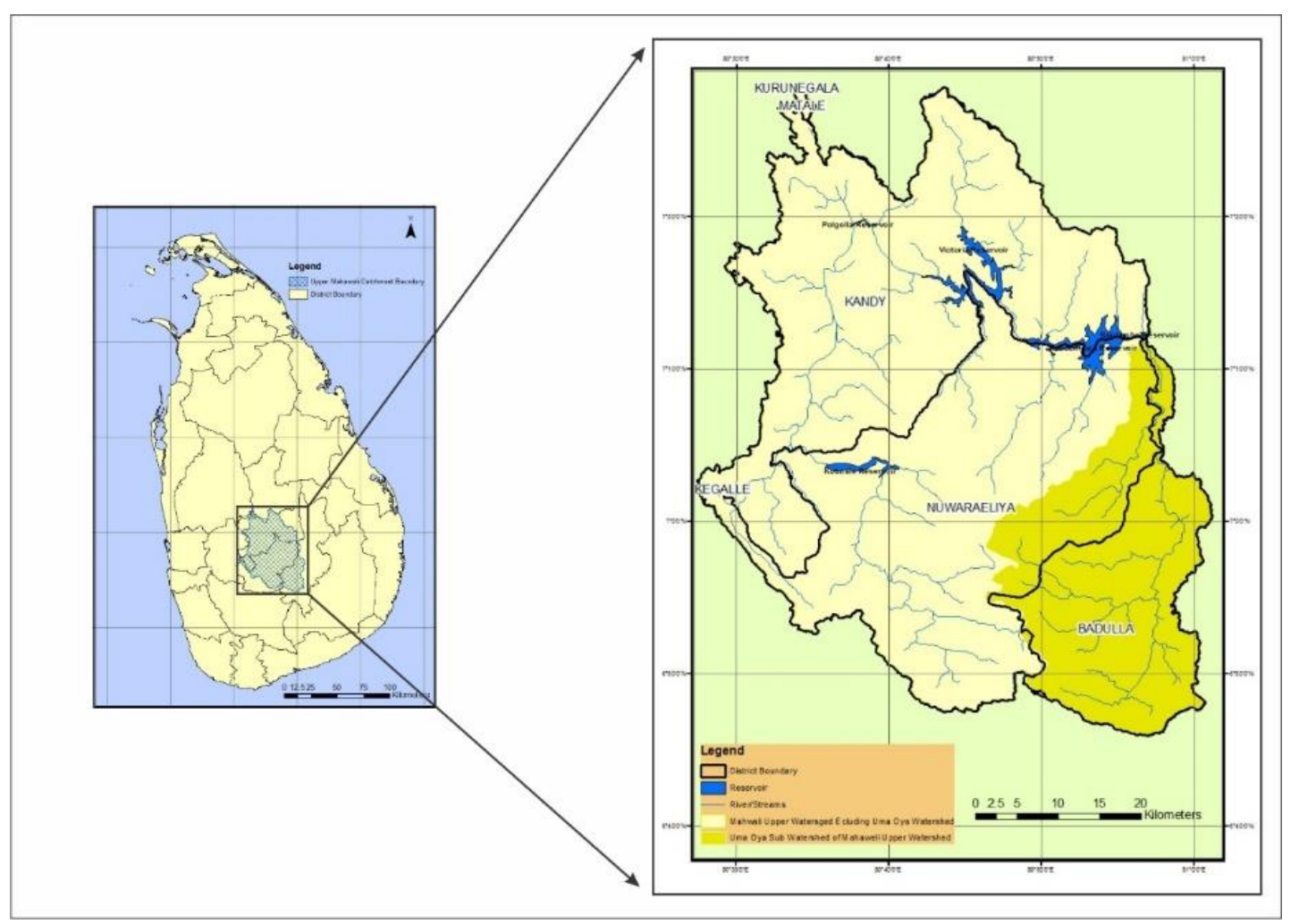

Figure 1: Study area map of Upper Mahaweli Catchment

Table 1: Satellite data specification used in the study

\begin{tabular}{lcccc}
\hline Data & $\begin{array}{c}\text { Year of } \\
\text { Acquisition }\end{array}$ & Bands & Resolution (m) & Source \\
\hline Landsat TM_5 & 1992 & Multispectral & $30 \mathrm{mX30m}$ & USGS \\
Landsat TM_8 & 2017 & Multispectral & $30 \mathrm{mX30m}$ & USGS \\
Google image & 2017 & Visible & $1 \mathrm{mX1m}$ & Google Earth \\
\hline
\end{tabular}

Department of Sri Lanka were used as ancillary data. Satellite data specifications are given in Table 1.

\section{Image pre-processing}

Image data were pre-processed using ERDAS imagine 2014 software for geo-referencing, mosaicking and sub-setting of the image, based on Area of Interest (AOI). Layer staking for colour composite for each year image was done for better contrast of images for better extraction of information.

\section{Classification using on-screen digitizing and visual interpretation.}

In this study, onscreen digitizing was done to map land use classes mentioned in Table 2. This method was used due to observation of misclassifications observed after implementing automated image classification using ERDAS imagine software. Since spectral signatures of forests and homegardens are similar, spectral overlaps were observed resulting misclassifications in image analysis. In addition, spectral overlapping was observed between tea and homegardens as well. Interpretation elements such as tone/hue, texture, size, shape, pattern, association were used for interpretation. Homegardens can see red colour/hue in the false colour composite of satellite image. This is not adequate to decide homegarden land use class. The texture of the image is course in homegardens compared to forests due to presence of roofs of houses scattered in homegarden area. In addition, garden area of the homegarden with small trees and ornamental plants and bare patch closer to the house are also reasons for course texture. Site is the other important interpretation element in identifying homegardens. Roads, cluster of buildings, paddy lands are located closer to homegardens and they appear in different 
hues/colours in the image. Size of the homegardens cluster is smaller than forests. The knowledge and experience about the area was also used. In addition, Google images, 1: 50,000 topographic maps, aerial photographs were used as ancillary data to identify land use classes. However, Google images were not available to prepare land use map for 1992. Therefore, alternative approaches were adopted as stated by Wagner et. al. (2013). Onscreen digitizing was adapted with proper interpretation elements and using ancillary data of 1: 50,000 topographic maps to prepare land use map of 1999. Arc GIS-10 software was used for the on-screen digitizing, change detection and analysis of spatial data.

\section{Accuracy assessment}

The accuracy assessment was done for 2017 classified map using field observations supported by google images. However, for 1992 field observation is not possible. Google images are also not available in 1992 and geo referenced aerial photographs were also not available to take as reference. The 1992 topographic maps do not have the same legend for comparison. Therefore, it was not possible to do accuracy assessment for 1992. However, onscreen digitizing was adapted with proper interpretation elements and using ancillary data of 1:50,000 topographic maps to maintain a fare accuracy. In the face of a lack of independent training data for the historical image alternative approaches can be adopted (Asubonteng et. al. 2018). In total, 280 random reference points to cover all land use types within the catchment were recorded along with the field survey using a Global Position System (GPS) in the study area to produce error matrix for 2017 classified map. The methodology followed in this study to detect changes was the "Post classification comparison" based on Dimyati et al. (1996), Jensen (2005) and Fichera et al. (2012).

\section{Post classification change detection}

Change detection analyses describes and quantify differences between images of the same scene at different times. In this analysis classified images of 1992 and 2017 were used to detect changes. It required sufficient time to detect noticeable spatial changes in a large area of a country specially for large scale catchments as UMC to and to detect determinants of changes (Rathnayake et al. 2020; Haque et al., 2017; Perera and Tsuchiya, 2009). Therefore, spatial, and temporal analysis of this study was based on 25-year period. The methodology followed in this study to detect changes was the "Post classification comparison" based on Jensen (2005), Fichera et. al. (2012) and Dimyati et al. (1996).

\section{Determinants for spatial and temporal changes of homegardens}

The changes of homegarden land use in UMC depend on various environmental, socio economic, spatial and demographic determinants. To understand effect of spatial variables visual analysis using maps was done. In order develop maps including spatial variables, Digital Elevation Models and Grama Niladhari Division (GND) maps were also used. A grade and B grade roads were digitized and used for distance analysis. A multiple linear regression model was implemented along with the spatial assessment to determine the biophysical and socio-economic drivers for changes of TROF in UMC using the following model.

$y=\alpha+\beta_{1} X_{1}+\beta_{2} X_{2}+\ldots+\beta_{n} X_{n}+\epsilon$

where, $y$ is percentage area of land use change from one class to other land use class in a GND in 2017 compared to $1992, \alpha, \beta$ are coefficients, and $\mathrm{xi}_{\mathrm{i}}$ is explanatory variables aggregated to GNDs.

Table 2: Description of land use/ land cover classes

\begin{tabular}{ll}
\hline Land use classes & Description \\
\hline Forest \& shrubs & Dense forests, spars forests, forest plantations and shrubs \\
Homegardens & Homegarden clusters with tree components \\
Tea & Tea plantations \\
Paddy & Paddy fields \\
Other Agricultural lands & Agricultural areas with annual cash crops and vegetables including chena \\
& $\begin{array}{l}\text { cultivation } \\
\text { Bare land and Grass }\end{array}$ \\
Water bodies & Bare ground, vacant lands, open area, and fallow lands including grasslands \\
Urban & Reservoirs, rivers, streams and lakes \\
& Urban, residential, commercial, industrial, transportation, roads, sub-urbs \\
& and mixed urban settings. \\
\hline
\end{tabular}


Since the major land use change is other agricultural crops to homegardens the dependent variable $y$ for this analysis is

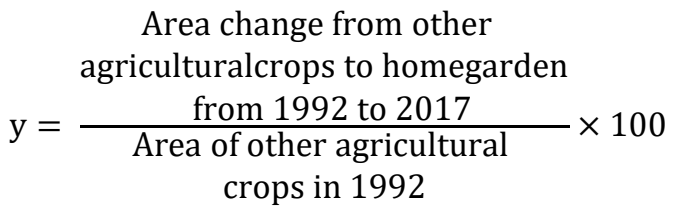

Explanatory variables used in the above model are listed in the Table 3. Secondary data sources and methodology used for generation of value of each variable in the model also listed in the same. To run this model land use change were aggregated to a GND as a cluster. Therefore, explanatory variables were averaged to the GND. GND is one the best unit analysis for socio-economic assessments due to presence of reliable socio-economic data which is needed for the entire catchment available in the Department of Senses and Statics in Sri Lanka. The size variation of GNDs was overcome by using percentage values for variables. Data analysis was done using STATA 12.1 software. Multi collinearity was tested for the explanatory variables using Variance Inflation Factor (VIF).

\section{RESULTS AND DISCUSSION}

\section{Spatial distribution of land uses in Upper Mahaweli Catchment}

Land use maps prepared for 1992 and 2017 illustrate the spatial distribution of land uses in the catchment for both years as depicted in Figures $2 \mathrm{a}$ and $\mathrm{b}$, respectively. According to spatial assessment the main land use type of the catchment is forests, and it is around 93,000 ha in both years (Table 5). According to the Table 5, the area under tea is 78,500 ha in 1992 and it has been reduced to 67,400 ha in 2017 by $14 \%$. Homegarden occupies 53,000 ha in 1992 and it was increased to 85,000 ha in 2017 by $60 \%$. Area under other agricultural crops have been decreased from 1992 to 2017 by 14,000 ha or by $42 \%$. An increment of homegardens in the catchment is favorable for the sustainability of the catchment since homegardens provide most of the ecosystem services despite occur in small extents. Although individuals owned a small area

\begin{tabular}{|c|c|}
\hline Variable & Data source / Method of Generation \\
\hline \multicolumn{2}{|l|}{ Environmental variables } \\
\hline Average Slope percentage of a GND & $\begin{array}{l}\text { Surface analysis of USRTM Digital Elevation Model and } \\
\text { mean slope for GNDs were estimated using zonal statistics } \\
\text { tool in ArcGIS. }\end{array}$ \\
\hline Average Elevation (m) of a GND & $\begin{array}{l}\text { SRTM Digital Elevation Model and mean elevation for GNDs } \\
\text { were estimated using zonal statistics tool in ArcGIS. }\end{array}$ \\
\hline Agro Ecological Zone that GND located. & Agro Ecological Zone and GND map \\
\hline \multicolumn{2}{|l|}{ Spatial variables } \\
\hline $\begin{array}{l}\text { Distance to the GND from A or B grade } \\
\text { road }\end{array}$ & $\begin{array}{l}\text { Proximity analysis was done using Road shape file and GND } \\
\text { shape using near tool. }\end{array}$ \\
\hline $\begin{array}{l}\text { Distance to the nearest town center of } \\
\text { Municipal Council or Urban Council. }\end{array}$ & $\begin{array}{l}\text { Proximity analysis was done using Urban council and } \\
\text { Municipal council, shape file and GND shape using near tool. }\end{array}$ \\
\hline \multicolumn{2}{|l|}{ Demographic variables } \\
\hline Population Density of GND & Department of Census and Statistics \\
\hline $\begin{array}{l}\text { Percentage of employed population in } \\
\text { GND }\end{array}$ & Department of Census and Statistics \\
\hline $\begin{array}{l}\text { Percentage of population education } \\
\text { below GCE }(0 / \mathrm{L})\end{array}$ & Department of Census and Statistics \\
\hline \multicolumn{2}{|l|}{ Socio-Economic variables } \\
\hline Poverty Head Count index of GND & Department of Census and Statistics \\
\hline
\end{tabular}
of land the aggregate effect is prominent. However, the quality and quantity of ecosystem

Table 3: Explanatory variables and their description 
services may depend upon the quality of homegarden land use in terms of its tree density, tree diversity and canopy cover (Pushpakumara et al., 2012).

\section{Results of accuracy assessment}

The accuracy assessment was done for the land use categories of classified map of 2017 and the overall accuracy was $82 \%$ as shown error matrix in Table 4. However, accuracy assessment for 1992 classification was not done due to inability of obtaining true land use classes from field observation and unavailability of higher accuracy maps such as google images were not available for 1992. Since onscreen digitizing was done with ancillary data for classification, it is assumed that fare accuracy has been obtained for 1992 .

\section{Major land use changes}

According to the spatial assessment, major changes over the last 25 years in UMC as indicated in the land use maps and change detection matrix was conversion of 13,700 ha of other agricultural lands into homegardens during estimated period (Table 5). In addition, 9,000 ha of tea lands were changed into homegardens during the same period. It was observed during field investigations that

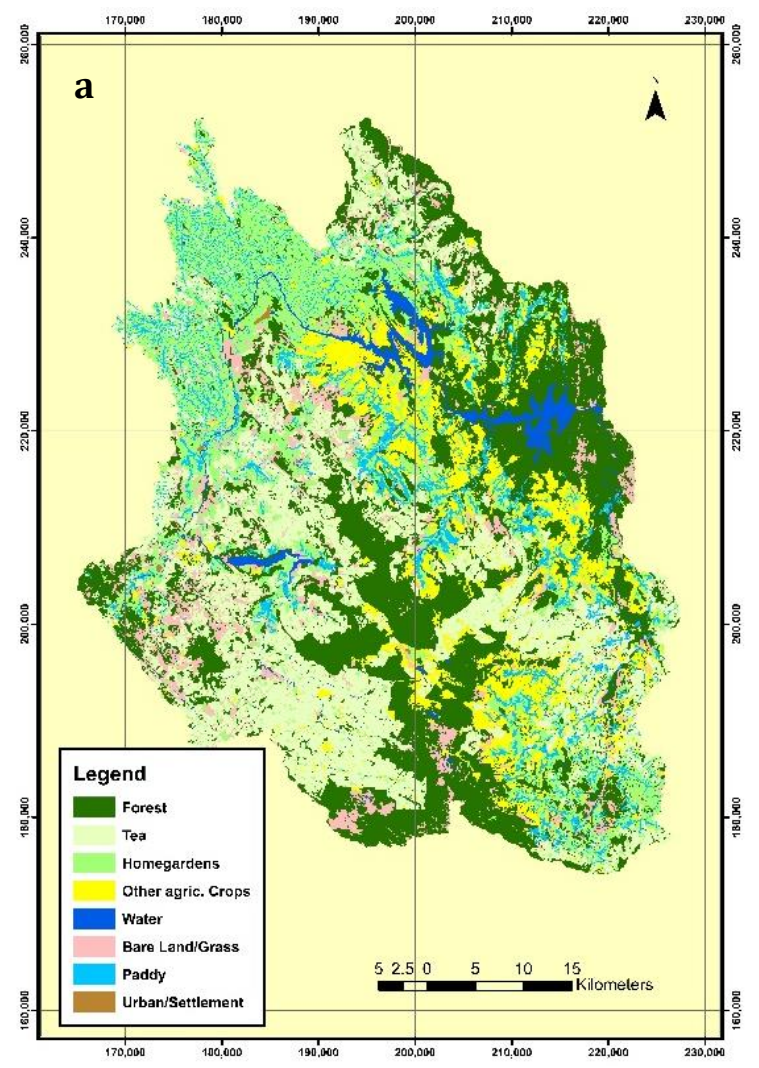

unproductive tea lands and abandoned degraded lands covered by grasses for sometimes have been converted into tree rich homegardens in both Kandy and Badulla district which have been occupied by people later for residing purposes. This has been confirmed during field observation for ground verification process carried out for image classification too. According to the assessment carried out by FAO shows that loss of forest cover in some regions of the world were partially offset by a combination of natural expansion, often on abandoned agriculture and the establishment of planted forests (FAO, 2016). The similar situation was revealed on enhancing tree cover in the UMC by converting abandoned tea lands into homegardens. Other important land use change is conversion of 1,000 ha of homegardens to urban land use during the same period.

Out of these changes, special emphasis was given in this paper to describe the conversion of other agricultural crop based (cash crops and vegetables) land use in to homegardens as the major land use change which has been revealed by this study, considering the potential sever impacts caused by unsustainable cultivation practices negatively to the qualities of the UMC specially at higher elevations.

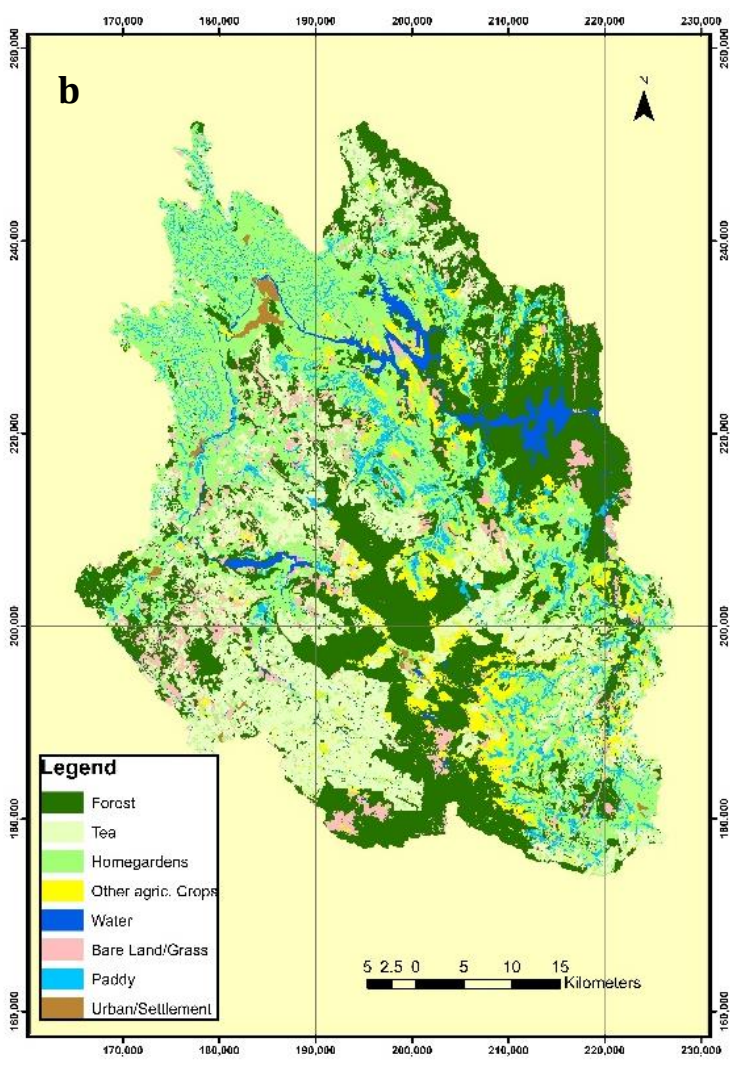

Figure 2: Land use map of Upper Mahawali Catchment in 1992 (a) and in 2017 (b) 
Table 4: Error matrix for accuracy assessment

\begin{tabular}{|c|c|c|c|c|c|c|c|c|c|c|c|c|}
\hline & \multirow[b]{2}{*}{ Land use } & \multicolumn{8}{|c|}{ Actual } & \multirow[b]{2}{*}{$\begin{array}{r}\text { Total } \\
\text { Classified }\end{array}$} & \multirow[b]{2}{*}{$\begin{array}{r}\text { Error of } \\
\text { Commission }\end{array}$} & \multirow[b]{2}{*}{$\begin{array}{r}\text { User } \\
\text { Accuracy }\end{array}$} \\
\hline & & $\begin{array}{l}\text { Bare/ } \\
\text { Grass }\end{array}$ & Forest & $\begin{array}{r}\text { Home } \\
\text { Gardens }\end{array}$ & $\begin{array}{c}\text { Other } \\
\text { Agri. } \\
\text { Crops }\end{array}$ & Paddy & Tea & Urban & Water & & & \\
\hline \multirow{11}{*}{ 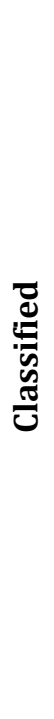 } & Bare/Grass & 12 & 5 & 2 & 0 & 1 & 1 & 0 & 0 & 21 & 43 & 57 \\
\hline & Forest & 1 & 69 & 1 & 1 & 0 & 1 & 0 & 0 & 73 & 5 & 95 \\
\hline & Home Gardens & 2 & 11 & 53 & 3 & 1 & 1 & 0 & 0 & 71 & 25 & 75 \\
\hline & $\begin{array}{l}\text { Other Agri. } \\
\text { Crops }\end{array}$ & 1 & 3 & 2 & 17 & 1 & 1 & 0 & 0 & 25 & 32 & 68 \\
\hline & Paddy & 3 & 1 & 1 & 2 & 15 & 0 & 0 & 0 & 22 & 32 & 68 \\
\hline & Tea & 2 & 1 & 1 & 0 & 0 & 57 & 0 & 0 & 61 & 7 & 93 \\
\hline & Urban & 0 & 0 & 1 & & 0 & 0 & 2 & 4 & 3 & 33 & 67 \\
\hline & Water & 0 & 0 & 0 & 0 & 0 & 0 & 0 & 4 & 4 & 0 & 100 \\
\hline & Total (2017) & 21 & 90 & 61 & 23 & 18 & 61 & 2 & 4 & 280 & 100 & 0 \\
\hline & $\begin{array}{l}\text { Error of } \\
\text { Omission }\end{array}$ & 43 & 23 & 13 & 26 & 17 & 7 & 0 & 0 & & & \\
\hline & $\begin{array}{l}\text { Producer } \\
\text { Accuracy\% }\end{array}$ & 57 & 77 & 87 & 74 & 83 & 93 & 100 & 100 & \multicolumn{2}{|c|}{ Overall Accuracy } & $82 \%$ \\
\hline
\end{tabular}


Table 5: Land use change matrix (1992 -2017)

\begin{tabular}{|c|c|c|c|c|c|c|c|c|c|c|}
\hline & \multirow[b]{2}{*}{ Land Use } & \multicolumn{8}{|c|}{2017 Land area ha } & \multirow[b]{2}{*}{$\begin{array}{r}\text { Total } \\
(1992)\end{array}$} \\
\hline & & $\begin{array}{l}\text { Bare/ } \\
\text { Grass }\end{array}$ & Forest & $\begin{array}{r}\text { Home } \\
\text { Gardens }\end{array}$ & $\begin{array}{l}\text { Other } \\
\text { agric. } \\
\text { Crops }\end{array}$ & Paddy & Tea & $\begin{array}{c}\text { Urban/ } \\
\text { settlement }\end{array}$ & Water & \\
\hline \multirow{9}{*}{ 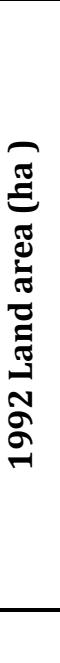 } & Bare/Grass & 14,671 & 4,169 & 3,266 & 721 & 35 & 1,167 & 41 & 18 & 24,087 \\
\hline & Forest & 2,305 & 82,006 & 4,685 & 1,840 & 193 & 1,746 & 18 & 7 & 92,800 \\
\hline & Home Gardens & 132 & 600 & 50,658 & 343 & 309 & 164 & 1,049 & 3 & 53,258 \\
\hline & $\begin{array}{l}\text { Other agric. } \\
\text { Crops }\end{array}$ & 573 & 2,712 & 13,748 & 14,725 & 710 & 332 & 116 & 6 & 32,923 \\
\hline & Paddy & 84 & 249 & 3,899 & 409 & 16,282 & 16 & 95 & 1 & 21,036 \\
\hline & Tea & 907 & 3,399 & 9,093 & 991 & 138 & 64,006 & 19 & 10 & 78,562 \\
\hline & $\begin{array}{l}\text { Urban } \\
\text { /settlement }\end{array}$ & - & - & - & - & - & - & 224 & - & 224 \\
\hline & Water & 1 & - & 4 & - & - & - & 26 & 8,248 & 8,280 \\
\hline & Total (2017) & 18,673 & 93,135 & 85,353 & 19,029 & 17,667 & 67,431 & 1,589 & 8,293 & 311,170 \\
\hline
\end{tabular}




\section{Land use change and elevation}

Distribution of other agricultural lands in 1992 was analyzed for different elevation categories and Figure 3 shows that majority of these lands are distributed in elevation above $500 \mathrm{~m}$. Changes of other agricultural crops into homegardens from 1992 to 2017 in different elevations were also assessed using the change map (Figure 4). Table 6 shows that $45.9 \%$ and $31.8 \%$ of the other agricultural crop lands are located in between $500 \mathrm{~m}-1,000 \mathrm{~m}$ elevation category and 1,000m $1,500 \mathrm{~m}$ elevation categories, respectively. Qasim (2013) illustrated that land use change processes vary quite considerably between different altitudinal zones. A study conducted to analyze drivers and implications of land use/land cover dynamics in Finchaa Catchment, Northwestern Ethiopia (Dibaba et al., 2020) have explained the relationship between land use change and elevation. The study stated that the construction of the reservoir had displaced farmers and caused land scarcity. Because of the scarcity of land, coupled with the need to farm more land, has led the community to cultivate steep slopes.

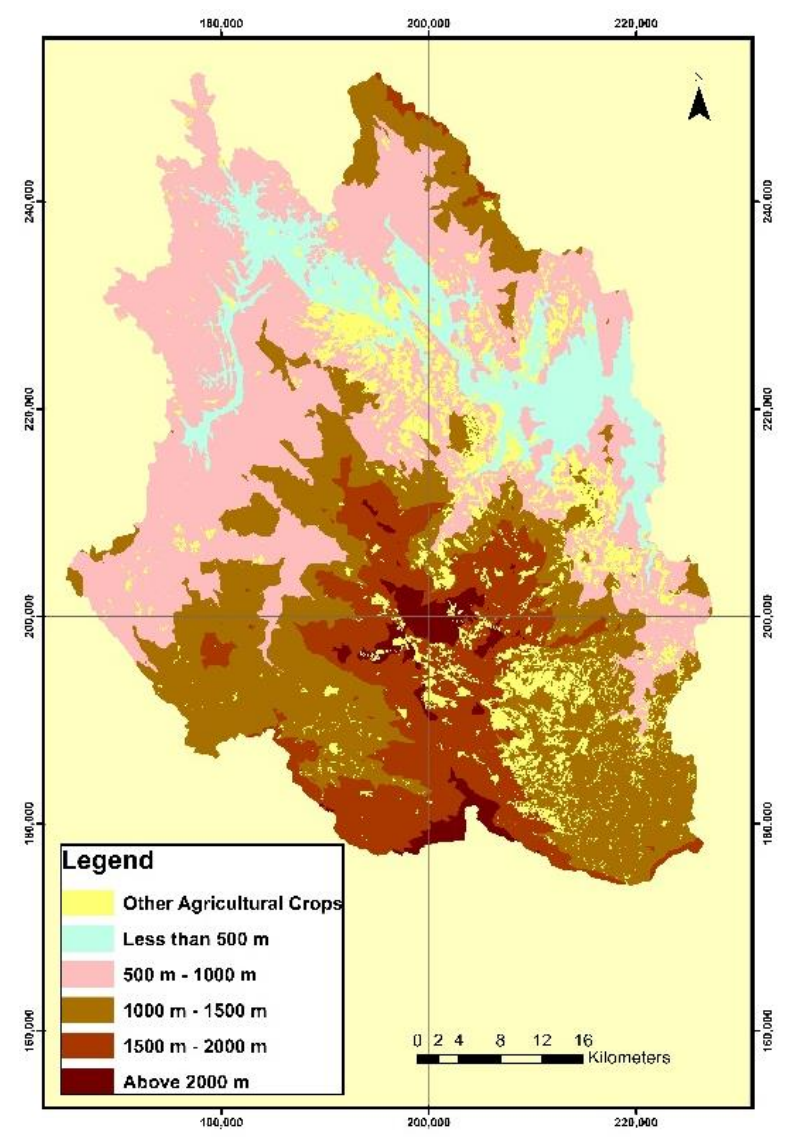

Figure 3: Distribution of other agricultural crop lands in 1992 in elevation categories
Changes of other agricultural lands from 1992 to 2017 into homegardens were analyzed for same elevation categories. Figure 5 shows most converted lands (51.1\%) are distributed in the elevation between $500-1,000 \mathrm{~m}$. This conversion is favorable for the catchment sustainability since it enhances tree cover of the catchment. However, it depends on the quality of homegardes in terms of quality parameters such as tree density, tree diversity and biodiversity. Nevertheless, comparatively less amount of other agriculture and vegetable-based land use area have been converted into homegardens by $13.2 \%$ and $10.2 \%$, respectively within elevation categories of $1,500 \mathrm{~m}$ $-2,000 \mathrm{~m}$ and above 2,000 $\mathrm{m}$ (Table 6). It indicates that there is low tendency to establish a permanent tree cover at higher elevation category. Presence of permanent tree cover at higher elevation is essential for catchment protection. Considering this issue forest ordinance was amended in 1938 to ban clearing of forests above 5,000 feet elevation for plantations and to be gradually converted to indigenous species (FSMP, 1995).

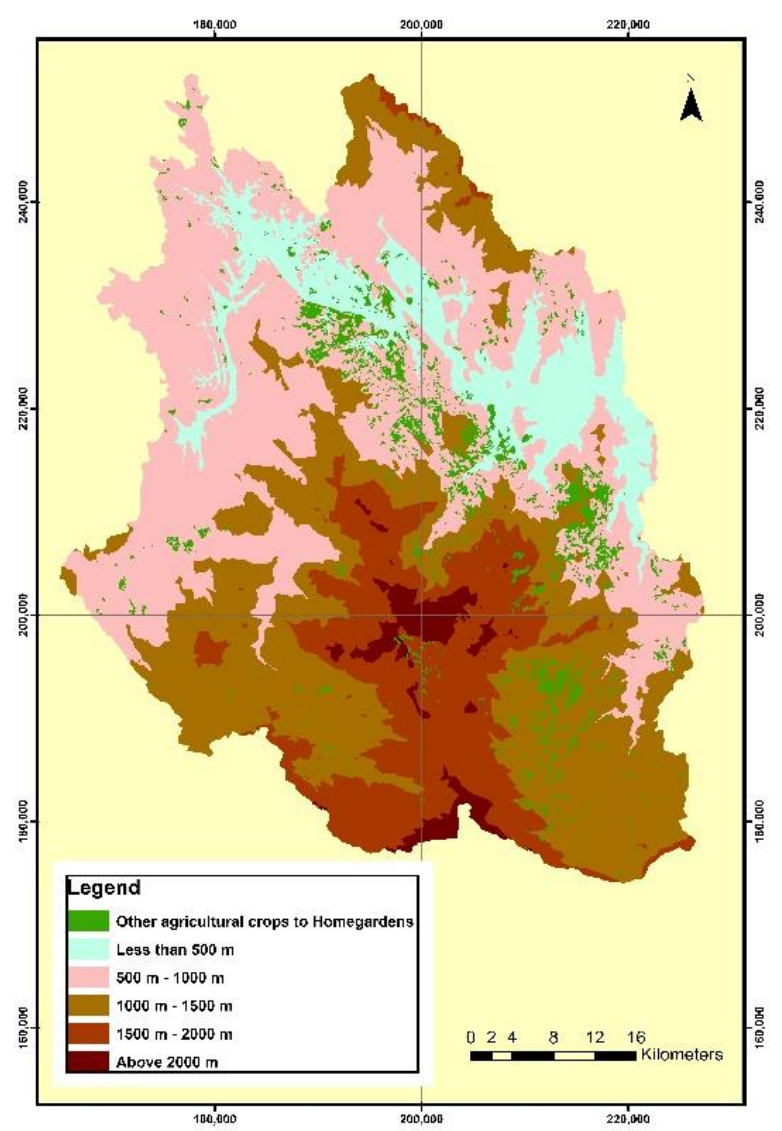

Figure 4: Distribution of other agricultural crop lands coverted in to homegardens from 1992 to 2017 in elevation categories 
Table 6: Changes of other agricultural crops into homegardens from 1992 to 2017 in different elevations

\begin{tabular}{|c|c|c|c|c|}
\hline $\begin{array}{l}\text { Elevation } \\
\text { Category (m) }\end{array}$ & $\begin{array}{r}\text { Other } \\
\text { agricultural } \\
\text { crops in } \\
1992 \text { (ha) } \\
\end{array}$ & $\begin{array}{r}\text { Percentage of } \\
\text { the Total }\end{array}$ & $\begin{array}{r}\text { Other agricultural } \\
\text { areas change in } \\
\text { homegardens from } \\
1992-2017 \text { (ha) }\end{array}$ & $\begin{array}{r}\text { Percentage of } \\
\text { change from 1992- } \\
2017 \text { compared to } \\
1992 \\
\end{array}$ \\
\hline Less than 500 & 3,387 & 10.3 & 1,464 & 43.2 \\
\hline $500-1,000$ & 15,093 & 45.9 & 7,710 & 51.1 \\
\hline $1,000-1,500$ & 10,458 & 31.8 & 4,054 & 38.8 \\
\hline $1,500-2,000$ & 3,557 & 10.8 & 471 & 13.2 \\
\hline Above 2,000 & 416 & 1.3 & 42 & 10.2 \\
\hline
\end{tabular}

\section{Biophysical and Socio-economic determinants for changes}

Table 7 presents the results of the multiple linear regression model to evaluate determinants for changes of other agricultural crops-based land uses into homegardens. The multi collinearity was tested for the explanatory variables using Variance Inflation Factor (VIF) and found all variables have the VIF value less than 10 . It shows that multi collinearity does not exists. The $\mathrm{R}^{2}$ is $27 \%$ for the linear model. The results show that the percentage change from other agricultural crops to homegardens is significantly $(p<0.01)$ decreasing with increasing the mean elevation of GNDs. That means in higher elevations farmers prefer to maintain their other agricultural lands without changing them into homegardens. The main reason revealed during field observation was the lucrative vegetable cultivation practice intensively in these area in the UMC. Therefore, in critical areas in the catchment where forest cover is low, are highly vulnerable to soil erosion due to inappropriate agriculture practices (Wickramagamage,1990). In addition, intensive agricultural activities in these areas causing water pollution (Henegama et al., 2013) too. The principal adverse environmental impacts found within the Mahaweli basin include on-site soil loss rates, particularly in the upper catchment, continue to be greater than soil replacement rates (USAID, 1993). Therefore, special attention should be paid for this decreasing trend of this major change in this critical area of the catchment.

The distance to main road and distance square jointly significant $(p<0.1)$. There is a parabolic relationship between distance and percentage change of other agricultural land use into homegardens. It shows that change is higher in closer to the main road and reduces with the distance. After a certain distance, the change percentage is increasing. It is due to an increasement of settlements in village level by converting other agriculture-based land into homegardens. Similar results suggest that distance to roads is also found positively associated with the agriculture land use conversion by Farah et al. (2019). According to Farah et al. (2019) every $1 \mathrm{~km}$ decrease in distance to main road, increases the ratio of agricultural land conversion by $83.2 \%$.

The percentage change from other agricultural crops to homegardens is positively and significantly $(p<0.00)$ change with distance to GNDs from the main town. It shows the more changes of other agricultural crops to homegardens is higher in village areas compared to town areas. The results of this study resonate with a study conducted in rural Ghana. According to the study, it had been revealed that an increasing rate of agricultural land use conversions can be observed because of increasing demand for residential land usage at the expense of agricultural land uses (Appiah et al., 2019).

According to Turner and Mayer (1994) change in population size, distribution and associated demographic characteristics are often considered as the most important factors affecting land use distribution and change. In this study, population density of the GNDs is positively significant $(\mathrm{p}<$ 0.001). It shows the percentage change from other agricultural crops to homegardens increase with the population density of the GNDs. People convert part of their crop lands to build houses for reside when population is high. The acceleration of development in the urban and suburbs due to an increase in population has led to the conversion of productive agricultural land to the use of quite complex spaces (Xia et al., 2020).

Munthali et al. (2019) revealed that poverty is a contributory factor for land use and land cover change. In this study, poverty head count index of 
Table 7: Results of multiple linear regression analysis on percentage change of other agricultural crops in 1992 to homegardens in 2017 in GNDs

\begin{tabular}{|c|c|c|c|c|}
\hline Variable & $\begin{array}{r}\text { Coefficient } \\
\text { estimate }\end{array}$ & $\begin{array}{r}\text { Standard } \\
\text { Error }\end{array}$ & t value & Probability \\
\hline \multicolumn{5}{|l|}{ Environmental variables } \\
\hline Average Slope percentage of a GND & -0.16512 & 0.171919 & -0.96 & 0.337 \\
\hline Average Elevation (m) of a GND & $-0.02527^{* * *}$ & 0.00600 & -4.21 & 0.000 \\
\hline \multicolumn{5}{|l|}{ Spatial variables } \\
\hline Distance to the main road & $-0.00407^{*}$ & 0.002182 & -1.87 & 0.062 \\
\hline Distance to the main road square & $8.75 \mathrm{e}-07^{* *}$ & 4.33E-07 & 2.02 & 0.044 \\
\hline Distance to the nearest town & $0.00089^{* * *}$ & 0.000326 & 2.73 & 0.006 \\
\hline \multicolumn{5}{|l|}{ Demographic variables } \\
\hline Population Density of GND & $0.24749^{* * *}$ & 0.064987 & 3.81 & 0.000 \\
\hline Percentage of employed population in GND & 0.003391 & 0.093124 & 0.04 & 0.971 \\
\hline $\begin{array}{l}\text { Percentage of population education below } \\
\text { GCE }(0 / L)\end{array}$ & $0.36653^{* *}$ & 0.1703 & 2.15 & 0.032 \\
\hline \multicolumn{5}{|l|}{ Economic variables } \\
\hline Poverty Head Count index of GND & $-1.4732^{* * *}$ & 0.319049 & -4.62 & 0.000 \\
\hline \multicolumn{5}{|l|}{ Agro ecological zone effect } \\
\hline Agro ecological zone fixed effect & \multicolumn{4}{|c|}{ Yes } \\
\hline No. of observations & \multicolumn{4}{|c|}{940} \\
\hline Test & \multicolumn{4}{|c|}{ F value: $11.62^{* * *}$} \\
\hline Probability value & \multicolumn{4}{|c|}{0.0000} \\
\hline R-squared & \multicolumn{4}{|c|}{0.2703} \\
\hline Adjusted R-squared & \multicolumn{4}{|c|}{0.2470} \\
\hline
\end{tabular}

Note: ${ }^{* * *} \mathrm{p}<0.01,{ }^{* *} \mathrm{p}<0.05,{ }^{*} \mathrm{p}<0.1$

the GNDs is negatively effect to the conversion significantly $(\mathrm{p}<0.01)$. This implies that conversion of other agriculture crops-based land uses to homegarden land uses decrease with the increase of poverty. Most of the people living in remote area whom below the poverty level tend to depend on annual cash crops and vegetables specially in Nuwara-eliya and Badulla district of UMC. Education of household head significantly associated with agricultural land conversion decision of farmers (Farah, 2019). Percentage of the population below GCE $\mathrm{O} / \mathrm{L}$ is positively and significantly $(\mathrm{p}<0.05)$ related with the land use change percentage. It shows that when people get less educated, they compel to settle down agriculture based remote areas to earn returns from agriculture without migrating to urban areas. As a result, there is a possibility to increase homegarden land uses in situation where education level is low.

Common limitations found in spatial assessments also encountered in this analysis such as misclassification errors arising during classification, validation of the accuracy of past land uses when studying land uses changes across long periods due to lack of ancillary data specially for the preparation of historical maps. Although a variety of methodological issues related to comparing land-use data derived from different data sources complicate the study of land-use change processes across long periods, the outcomes provide useful information for decision making. Perhaps more importantly, many land-use change processes are time dependent. These temporal issues have serious implications for landuse change analysis in terms of identifying the relationship of these land-use changes within the context of varying factors (Agarwal et al., 2002).

\section{CONCLUSION}

The study indicates that considerable changes in land uses have been experienced over the past 25year period in the UMC. Both bio-physical and 
socio-economic forces are responsible for the changes. One of the important outcomes generated by this is that the extent of forest cover is remained the same over the last few decades. This would be due to successful implementation of forest protection regulations in the catchment area. However, there is a little or no opportunities to extend forest cover in the catchment area mainly due to shortage of land. Hence it is essential to look for alternative land uses which can be compensate the lack of forest cover in the catchment to some extent. The increasing trend of homegarden land use during the same period is favorable for the sustainability of the catchment in areas where the forest cover is lacking. However, the ecosystem services that can be generated from the homegardens are highly depend on the quality of them in terms of biodiversity. Therefore, it is appropriate to analyze the changes of the quality of homegardens in the catchment over the same period to take measure to improve them.

The other import finding is this study is the low conversion of other agriculture (cash crops and vegetable-based) land use system into homegardens or TROF based land use systems at the higher elevation of the catchment compared to moderate and lower elevation zones in the catchment. Therefore, special attention should be paid for the higher elevation zones where annual cash crops and vegetables intensely grow since the conversion is low. In order to sound

\section{REFERENCES}

Agarwal C., Glen, M.G., Grove, J.M., Evans, T.P. and Schweik, C.M. (2002). A Review and Assessment of Land-Use Change Models: Dynamics of Space, Time, and Human Choice. Center for the Study of Institutions, Population, and Environmental Change, Indiana University, United States.5-9.

Ariyadasa, K.P. (2002). Assessment of Tree Resources in the Home Gardens of Sri Lanka. EC-FAO Partnership Programme (2000-2002). Food and Agriculture Organization of the United Nations, Bangkok.8-23.

Appiah, D.O., Asante, F. and Nketiah, B. (2019). Perspectives on agricultural land use conversion and food security in rural Ghana. Science. 1(1),14. doi: 10.3390/sci1010014.v1

Asubonteng, K., Pfeffer, K., Ros-Tonen, M., Verbesselt, J. and Baud, I. (2018). Effects of treecrop farming on land cover transitions in a mosaic landscape in eastern region of Ghana. Environment Management. 62(3), 529-547. implementation of regulatory policies through the forest ordinance by making an amendment to band clearing of forests above 5,000 feet elevation in 1938 to maintain a permanent tree cover. It is a timely need to promote policy strategies to enhance permanent tree cover at higher elevations where lack of forest cover for the sake of catchment protection and to improve other ecosystem services derive from the UMC.

Considering the above facts, it can be concluded that, to reduce the risks of negative impacts due to lack of tree cover in the UMC appropriate incentives should be introduced to take conservation measures as well as to introduce TROF based sustainable agroforestry systems such as tree rich homegardens with divers tree components to maintain the sustainability of the catchment.

\section{AKNOWLEDGEMENT}

The author wishes to express sincere thank towards South Asian Network for Development and Environmental Economics (SANDEE) for providing a research grant to collect primary data and for providing number of trainings to enhance the knowledge and research capabilities.

Dimyati, M., Mizuno, K., Kobayashi, S. and Kitamura, T. (1996). An analysis of land use/cover change in Indonesia. International Journal of Remote Sensing 17(5), 931-944.

Dibaba, W.T., Demissie, T. and Miegel, K. (2020). Drivers and implications of land use/land cover dynamics in Finchaa Catchment, Northwestern Ethiopia Land. Land 9(4), 113. doi:10.3390/land9040113

FAO. (2016). Forests and Agriculture: Land use challenges and opportunities. State of the World's Forests. Rome, Italy. 22..

FAO. (2013). Forests and Tree Resources Outside Forest are Essential for Global Food Security and Nutrition. Summary of the International Conference on Forests for Food Security and Nutrition held in FAO headquarters, Rome, Italy. 4.

FAO. (1998). Global Forest Resources Assessment - 2000: Terms and Definitions. Forest Resources Assessment Programme. - Working 
Paper No. 1, Rome, Italy. (www.fao.org/forestry/fo/ fra/docs/Fra/WP1 eng.pdf).

Farah, N., Khan, I A., Maan, A. A., Shahbaz, B. and Cheema, J.M. (2019). Driving factors of agriculture land conversion at rural-urban interface in Punjab. Pakistan. Journal of Agricultural Research. 57(1), 55-62.

Fichera, C.R., Modica, G. and Pollino, M. (2012). Land cover classification and change-detection analysis using multi-temporal remote sensed imagery and landscape metrics. European Journal of Remote Sensing. 45(1), 1-18

FSMP (1995). Sri Lanka Forestry Sector Master Plan, Forestry Planning Unit, Forest Department, Ministry of Agriculture, Lands and Forestry, Colombo, Sri Lanka. p.37.

Gunawardhana, W.D.T.M., Jayawardhana, J.M.C.K., Udayakumara, E.P.N. and Malavipathirana, S. (2018). Spatio-temporal variation of water quality and bio indicators of the Badulu Oya in Sri Lanka due to catchment disturbances. Journal of the National Science Foundation of Sri Lanka. 46(1), 51-67.

Gibbon, H. (1990). Land Use Planning in Upper Mahaweli Catchment, Technical Report. FOLUMP, Dangolla, Kandy, Sri Lanka.

Hevawasam, T. (2010). Effect of land use in the Upper Mahaweli Catchment area on erosion, landslides, and siltation in hydropower reservoirs of Sri Lanka. Journal of National Science Foundation Sri Lanka. 38 (1), 3- 14.

Hewavisenthi, A.C. (1997). Management of the Mahaweli, A River in Sri Lanka. Water International. 22(2), 98-107.

Henegama, H.P., Dayawansa, N.D.K., and De Silva S. (2013). An assessment of social and environmental implications of agricultural water pollution in Nuwara Eliya. Tropical Agricultural Research. 24(4), 304-316.

Haque., I. and Basak, R. (2017). Land cover change detection using GIS and remote sensing techniques: A spatio-temporal study on Tanguar Haor, Sunamganj, Bangladesh. The Egyptian Journal of Remote Sensing and Space Sciences. 20(2), 251-263.

Jensen, J.R. (2005). Introductory Digital Image Processing: A Remote Sensing Perspective. Prentice-Hall Inc., USA. 10-52..
Munthali, M.G., Davis, N., Adeola, A.M., Botai, J.O., Kamwi, J.M., Chisale, H.W. and Orimoogunje, O.O.I. (2019). Local perception of drivers of land-use and land-cover change dynamics across Dedza District, Central Malawi Region. Sustainability. 11 (3), 832. doi:10.3390/ su11030832.

Perera, K. and Tsuchiya, K. (2009). Experiment for mapping land cover and it's change in southeastern Sri Lanka utilizing $250 \mathrm{~m}$ resolution MODIS imageries. Advances in Space Research. 43(9), 1349-1355.

Pushpakumara, D.K.N.G., Marambe, B., Silva, G.L.L.P. Weerahewa, J. and Punyawardhana, B.V.R. (2012). A review of research on homegardens in Sri Lanka: the status, importance, and future perspective. Tropical Agriculturist. 160, 55-126.

Qasim, M., Hubacek, K., Termansen, M. and Fleskens, L. (2013). Modelling land use change across elevation gradients in district Swat, Pakistan. Regional Environmental Change. 13 (3), 567-581.

Ranjith Premalal De Silva, W.P. (1997). Spatiotemporal hydrological modelling with GIS for the Upper Mahaweli Catchment, Sri Lanka. Unpublished PhD Thesis 1997, Department of Natural Resources Management, Silsoe College, Cranfield University, UK.

Rathnayake, C.W.M., Jones, S. and Soto-Berelov, M. (2020). Mapping land cover change over a 25year period (1993-2018) in Sri Lanka using Landsat Time-Series. Land 9(1), 27. doi:10.3390/land9010027

Turner, B.L., Meyer, W.B. and Skole, D.L. (1994). Global land-use/land-cover change: towards an integrated study. 23(1), 91-95.

USAID (1993) Environmental Evaluation of the Accelerated Mahaweli Development Program: Lessons Learned and Donor Opportunities for Improved Assistance - 1993. Project Document. U.S. Agency for International Development, USA. PDC-545 1-1-14-1027-00

Wagner, P.D., Kumar, S. and Schneider. K. (2013). An assessment of land use change impacts on the water resources of the Mula and Mutha Rivers catchment upstream of Pune, India. Hydrology and Earth System Sciences. 17, 2233-2246. 
Wickramagamage, P. (1990). A man's role in the degradation of soil and water resources in Sri Lanka: a historical perspective. Journal of the National Science Council of Sri Lanka 18(1), 116.

Wijethunga Bandara. T.W.M.T. (2013). Changes in land use systems and their consequences. Social Sciences and Humanities Review. 1(1), 29-74.
Xia, M., Zhang, Y., Zhang, Z., Liu, J., Ou, W. and Zou, W. (2020). Modeling agricultural land use change in a rapid urbanizing town: linking the decisions of government, peasant households and enterprises. Land Use Policy: 90, 104266. https://doi.org/10.1016/j.landusepol.2019.10 4266. 